\title{
PERAN DINAS TATA RUANG DAN CIPTA KARYA DALAM PENGELOLAAN SAMPAH DI KABUPATEN BULUKUMBA
}

\author{
Akhmad Affandi ${ }^{1}$, Fatmawati² dan Adnan Ma'ruf² \\ 1Program Studi Ilmu Pemerintahan Fakultas Ilmu Sosial dan Ilmu Politik \\ Universitas Muhammadiyah Makassar \\ Jl Sultan Alauddin No 259 Makassar 90221 \\ Telp. 0411-866972 ext. 107. Fax. 0411-8655888 \\ Akhmadaffandi92@gmail.com \\ 2 Program Studi Ilmu Adminitrasi Negara Fakultas Ilmu Sosial dan Ilmu Politik \\ Universitas Muhammadiyah Makassar \\ Jl Sultan Alauddin No 259 Makassar 90221 \\ Telp. 0411-866972 ext. 107. Fax. 0411-8655888 \\ fatmawatiunismuh@gmail.com, adnan_maruf@yahoo.co.id
}

\begin{abstract}
This study aims to clarify the role and efforts of the Department of Spatial Planning and Human Settlements in managing waste in Bulukumba. This type of research is qualitative with data collection using interviews and observation instruments. The data is analyzed deskriktif and interpretation to the informant to conduct interviews. The results showed that: in carrying out the role as implementor and supervisor of the waste management in Bulukumba, Spatial Planning and Human Settlements Bulukumba can not yet provide the maximum results. Not maximal results are affected by the lack of human resources and lack of infrastructure are still available have greater influence in waste management. The contributing factors are: public participation and the availability of land (TPA).
\end{abstract}

Keywords: waste management, community participation

\begin{abstract}
ABSTRAK
Penelitian ini bertujuan untuk menjelaskan peran dan upaya Dinas Tata Ruang dan Cipta Karya dalam mengelola sampah di Kabupaten Bulukumba. Jenis penelitian ini adalah Kualitatif dengan teknik pengumpulan data menggunakan instrumen wawancara dan observasi. Data tersebut dianalisis secara deskriktif dan interpretasi kepada informan dengan melakukan wawancara. Hasil penelitian menunjukkan bahwa: dalam melaksanakan peran sebagai implementor dan pengawas terhadap pengelolaan sampah di Kabupaten Bulukumba, Dinas Tata Ruang dan Cipta Karya Kabupaten Bulukumba belum dapat memberikan hasil yang maksimal. Belum maksimalnya hasil tersebut dipengaruhi oleh kurangnya sumber daya manusia serta masih minimnya sarana dan prasarana yang tersedia memiliki pengaruh lebih besar dalam pengelolaan sampah. Adapun faktor pendukung yakni: partisipasi masyarakat dan ketersediaan lahan (TPA).
\end{abstract}

Kata kunci: pengelolaan sampah, partisipasi masyarakat 


\section{A. PENDAHULUAN}

Meningkatnya masalah persampahan berbagai kota di Indonesia tidak lepas dari laju urbanisasi yang cukup tinggi di berbagai wilayah perkotaan yang tidak diimbangi dengan penyediaan infrastruktur persampahan yang memadai. Kondisi ini tidak membaik dari tahun ke tahun. Permasalahan persampahan yang mengemuka secara nasional secara umum didominasi oleh wilayah perkotaan yang memiliki keterbatasan lahan TPA sehingga dampaknya tidak saja terhadap pencemaran lingkungan tetapi juga terhadap kesehatan. Perkembangan dan pertumbuhan penduduk yang pesat di daerah perkotaan mengakibatkan daerah pemukiman semakin luas dan padat. Peningkatan aktivitas manusia, lebih lanjut menyebabkan bertambahnya sampah.

Pengelolaan sampah meliputi pewadahan, pengumpulan, pengangkutan, pengolahan dan pembuangan akhir. Syarat yang harus terpenuhi dalam pengelolaan sampah ialah tidak mencemari udara, air dan tanah, tidak menimbulkan bau (segi estetis), tidak menimbulkan kebakaran dan lain sebagainya. Sehingga jelas bahwa pentingnya dalam pengelolaan sampah, karena melihat perkembangan waktu yang senantiasa diiringi dengan pertambahan penduduk yang berdampak terhadap jumlah timbulan sampah yang semakin meningkat sementara lahan yang ada tetap.

Menurut Sejati (dalam Khoiriyah 2010: 2), kerusakan lingkungan telah mengglobal karena perubahan iklim, timbul bencana, timbulnya pandemi penyakit, serta kelangsungan hidup manusia, tumbuhan, beserta binatang dan spesiesnya. Apabila tidak diatasi, bumi menjadi tidak nyaman untuk ditempati. Salah satu penyebab utama kerusakan lingkungan yaitu sampah.

Masalah lingkungan cukup memprihatinkan, rusaknya lingkungan karena adanya kegiatan ekonomi yang tinggi baik di sektor pertanian, industri, konsumsi energi dan pembuangan limbah sebagaimana yang terlihat sehari-hari limbah kemasan plastik, kaleng, kertas berserakan di jalan-jalan, di lorong-lorong, saluran drainase bahkan di laut. Tumpukan sampah tersebut dapat menciptakan tempat kehidupan tikus dan serangga lain serta bakteri yang dapat membahayakan kesehatan manusia bila berada di sekitar pemukiman penduduk.

Sampah, sebagaimana yang tertulis dalam Undang-undang No. 18 Tahun 2008, adalah sisa kegiatan sehari-hari manusia dan/atau proses alam yang berbentuk padat. Yang termasuk jenis sampah adalah sampah rumah tangga (tidak termasuk tinja), sampah sejenis sampah rumah tangga yang berasal dari kawasan komersial, kawasan industri, kawasan khusus, fasilitas sosial, fasilitas umum dan fasilitas lainnya serta sampah spesifik. Terakhir adalah sampah yang mengandung bahan berbahaya dan beracun dan limbah bahan berbahaya dan beracun, sampah yang timbul akibat bencana, puing bongkaran bangunan, sampah yang secara teknologi belum dapat diolah dan sampah yang timbul secara tidak periodik.

Dalam rangka membatasi ruang lingkup penelitian, maka peneliti hanya akan menfokuskan pembahasan pada lingkup "Peran Dinas Tata Ruang Dan Cipta Karya Dalam Pengelolaan Sampah Di Kabupaten Bulukumba" dimana selaku instansi pemerintahan yang bertanggung jawab sekaligus yang menangani masalah sampah di Kabupaten Bulukumba.

Seperti yang diketahui bahwa dalam mewujudkan suatu pembangunan yang berkualitas serta berkelanjutan haruslah senantiasa melibatkan seluruh stakeholders yang ada. Tidak mungkin suatu pembangunan akan berjalan dengan lancar jika tidak didukung oleh sebuah bentuk kerjasama yang baik, seperti 
halnya dengan pengelolaan masalah sampah yang harus dilakukan secara bersama-sama, baik itu pemerintah (Dinas Tata Ruang Dan Cipta Karya Kabupaten Bulukumba), masyarakat maupun pihak swasta. Keikutsertaan masyarakat dalam proses penanganan masalah sampah merupakan suatu bentuk kesadaran akan lingkungan sekitar sekaligus sebagai bentuk partisipasi dalam pembangunan.

Lebih dari pada itu kita dapat melihat kondisi realitas yang ada, dimana keberhasilan Kabupaten Bulukumba untuk pertama kalinya meraih piala adipura sebagai lambang supremasi penghargaan kebersihan kabupaten/kota kategori kota kecil pada tahun 2012.

Dengan meraih adipura yang kedua pada tahun 2013 semakin memperkuat eksistensi Kabupaten Bulukumba di kancah nasional sebagai Kabupaten yang mampu mengelolah dan menjaga kondisi kotanya agar tetap bersih. Raihan penghargaan yang kedua ini adalah sebuah bukti bahwa hubungan kerjasama antara pemerintah dan masyarakat semakin erat, apalagi jika itu menyangkut masalah kebersihan.

\section{B. KONSEPPERANAN PEMERINTAH DAERAH}

Menurut Undang-undang Nomor 32 Tahun 2004 tentang Pemerintahan Daerah, yang disebut dengan Pemerintah Daerah adalah Kepala Daerah beserta perangkat daerah otonom yang lain sebagai badan eksekutif daerah. Peranan Pemerintah Daerah dalam mendukung suatu kebijakan pembangunan bersifat partisipatif adalah sangat penting. Ini karena Pemerintah Daerah adalah instansi pemerintah yang paling mengenal potensi daerah dan juga mengenal kebutuhan rakyat setempat (Soetrisno, 1995 dalam Bahagia 2009:12).

Selanjutnya pelayanan publik pada dasarnya menyangkut aspek kehidupan yang sangat luas. Dalam kehidupan bernegara, maka pemerintah memiliki fungsi memberikan berbagai pelayanan publik yang diperlukan oleh masyarakat, mulai dari pelayanan dalam bentuk pengaturan ataupun pelayanan-pelayanan lain dalam rangka memenuhi kebutuhan masyarakat dalam bidang pendidikan, kesehatan dan lainnya. Pemerintah pada hakekatnya adalah pelayan masyarakat, ia tidaklah diadakan untuk melayani dirinya sendiri, tapi juga untuk melayani masyarakat serta menciptakan kondisi yang memungkinkan setiap anggota masyarakat mengembangkan kemampuan dan kreatifitasnya demi mencapai tujuan bersama ( Rasyid dalam Liata), karenanya birokrasi publik berkewajiban dan bertanggung jawab untuk memberikan layanan publik yang baik dan profesional. Dengan demikian pelayanan publik dapat diartikan sebagai pemberian layanan (melayani) keperluan orang atau masyarakat yang mempunyai kepentingan pada organisasi itu sesuai dengan aturan pokok dan tata cara yang telah ditetapkan. Pelayanan publik dapat diartikan melayani kepentingan masyarakat umum dalam sebuah negara. Pelayanan publik artinya memberikan pelayanan (melayani) keperluan masyarakata umum dalam sebuah negara (The Liang Gie dalam Liata).

Adapun tugas dan wewenang pemerintah pada pasal 6 dan 7 yang tercantum dalam Undang-undang Nomor 18 Tahun 2008 Tentang Pengelolaan Sampah pada Pasal 6 yakni tugas Pemerintah dan pemerintahan daerah antara lain: (1) Menumbuh kembangkan dan meningkatkan kesadaran masyarakat dalam pengelolaan sampah; (2) Melakukan penelitian, pengembangan teknologi pengurangan dan penanganan sampah; (3) Memfasilitasi, mengembangkan, dan melaksanakan upaya pengurangan, penanganan, dan pemanfaatan sampah; (4) Melaksanakan pengelolaan sampah dan memfasilitasi penyediaan prasarana 
dan sarana pengelolaan sampah; (5) Mendorong dan memfasilitasi pengembangan manfaat hasil pengolahan sampah; (6) Memfasilitasi penerapan teknologi spesifik lokal yang berkembang pada masyarakat setempat untuk mengurangi dan menangani sampah; dan (7) Melakukan koordinasi antar lembaga pemerintah, masyarakat, dan dunia usaha agar terdapat keterpaduan dalam pengelolaan sampah.

Selanjutnya pada Pasal 7: Dalam penyelenggaraan pengelolaan sampah, Pemerintah mempunyai kewenangan: (1) Menetapkan kebijakan dan strategi nasional pengelolaan sampah; (2) Menetapkan norma, standar, prosedur, dan kriteria pengelolaan sampah; (3) Memfasilitasi dan mengembangkan kerja sama antar daerah, kemitraan, dan jejaring dalam pengelolaan sampah; (4) Menyelenggarakan koordinasi, pembinaan, dan pengawasan kinerja pemerintah daerah dalam pengelolaan sampah; dan (5) Menetapkan kebijakan penyelesaian perselisihan antardaerah dalam pengelolaan sampah.

Sedangkan dalam Pasal 9 wewenang pemerintah Kabupaten/Kota adalah (1) Dalam menyelenggarakan pengelolaan sampah, pemerintahan kabupaten/kota mempunyai kewenangan;

Menetapkan kebijakan dan strategi pengelolaan sampah berdasarkan kebijakan nasional dan provinsi; (3) Menyelenggarakan pengelolaan sampah skala kabupaten/kota sesuai dengan norma, standar, prosedur, dan kriteria yang ditetapkan oleh Pemerintah; (4) Melakukan pembinaan dan pengawasan kinerja pengelolaan sampah yang dilaksanakan oleh pihak lain; (5) Menetapkan lokasi tempat penampungan sementara, tempat pengolahan sampah terpadu, dan/atau tempat pemrosesan akhir sampah; (6) Melakukan pemantauan dan evaluasi secara berkala setiap 6 (enam) bulan selama 20 (dua puluh) tahun terhadap tempat pemrosesan akhir sampah dengan sistem pembuangan terbuka yang telah ditutup; dan (7) Menyusun dan menyelenggarakan sistem tanggap darurat pengelolaan sampah sesuai dengan kewenangannya. Penetapan lokasi tempat pengolahan sampah terpadu dan tempat pemrosesan akhir sampah sebagaimana dimaksud pada ayat (1) huruf d merupakan bagian dari rencana tata ruang wilayah Kabupaten/Kota sesuai dengan peraturan perundang-undangan.

Lebih lanjut konsep mengenai pengelolaan sampah oleh pemerintah daerah tentunya mengacu dari subtansi dari sampah itu sendiri. Dimana, sampah adalah bahan yang tidak mempunyai nilai atau tidak berharga untuk maksud biasa atau utama dalam pembuatan atau pemakaian barang rusak atau bercacat dalam pembuatan manufaktur atau materi berkelebihan atau ditolak atau dibuang (Hendargo, dalam Afandi 2010:12). Dalam Undang-Undang Nomor 18 Tahun 2008 pasal (1) Sampah adalah sisa kegiatan sehari-hari manusia dan/atau proses alam yang berbentuk padat.

Menurut Undang-undang Nomor 18 tahun 2008, tentang Pengelolaan sampah, dalam pasal 3 yakni, pengelolaan sampah adalah kegiatan yang sistematis menyeluruh dan berkesinambungan yang meliputi pengurangan dan penangan sampah. Dalam amanah ini, disebutkan bahwa pengelolaan sampah diselenggarakan berdasarkan asas tanggung jawab azas berkelanjutan, asas mamfaat, asas keadilan. Asas kesadaran, kebersamaan, keselamatan, dan memiliki nilai ekonomi.

Pelaksanaan 3R tidak hanya menyangkut masalah sosial dalam rangka mendorong perubahan sikap dan pola pikir menuju terwujudnya masyarakat yang ramah lingkungan dan berkelanjutan tetapi juga menyangkut pengaturan (manajemen) yang tepat dalam 
pelaksanaannya. Prinsip pertama reduce adalah segala aktifitas yang mampu mengurangi dan mencegah timbulan sampah. Prinsip kedua reuse adalah kegiatan penggunaan kembali sampah yang layak pakai untuk fungsi yang sama atau yang lain. Prinsip ketiga recyle adalah kegiatan mengelola sampah untuk dijadikan produk baru.

\section{METODE PENELITIAN}

Penelitian ini memilih lokasi Kabupaten Bulukumba merupakan target daerah yang akan dijadikan sebagai lokasi penelitian. Jenis penelitian yang digunakan adalah pendekatan deskriptif kualitatif adalah pendekatan yang mementingkan adanya variabel-variabel sebagai obyek penelitian dan variabel tersebut didefinisikan Tipe penelitian adalah menggunakan tipe penelitian deskriptif sebagai usaha mengungkap suatu masalah atau peristiwa sebagaimana adanya sehingga bersifat mengungkap fakta dan memberikan gambaran keadaan obyektif tentang keadaan sebenarnya dari obyek yang diteliti. Sumber data dalam penelitian ini adalah data primer adalah data yang diperoleh dari responden dengan melalui observasi dan wawancara, yang berkaitan dengan masalah yang akan diteliti, dan data sekunder adalah data yang di ambil atau bersumber dari dokumen laporan, peraturan-peraturan yang berkaitan dengan masalah yang akan diteliti.

Adapun yang menjadi informan penelitian adalah Kepala Dinas Tata Ruang dan cipta karya kabupaten Bulukumba, Kepala Bidang sarana dan prasarana, kepala seksi kebersihan, pertamanan dan pemakaman serta tokoh masyarakat. Teknik pengumpulan data adalah: observasi yaitu teknik pengumpulan data yang diperoleh peneneliti melakukan pengamatan langsung, Wawancara yaitu teknik pengumpulan data dengan melakukan tanya jawab terhadap informan untuk memperoleh data yang berkaitan dengan permasalahan yang diteliti. Teknik analisis data yang telah dikumpulkan oleh peneliti diolah dan dianalisis dengan menggunakan metode kualitatif pengumpulan data dalam bentuk reduksi data, sajian data serta penarikan kesimpulan.

\section{PENELITIAN DAN PEMBAHASAN}

\section{Eksistensi Implementor dalam Mengebla Sampah}

Implementor adalah aktor yang mengimplementasikan kebijakan, sedangkan Implementasi kebijakan merupakan tahap yang penting dalam kebijakan. Tahap ini menentukan apakah kebijakan yang ditempuh oleh pemerintah benar-benar aplikabel di lapangan dan berhasil untuk menghasilkan output seperti yang telah direncanakan.

\section{a. Pengumpulan Sampah}

Pengumpulan sampah merupakan bentuk teknis kegiatan menyatukan sampah dalam suatu wadah. Bentuk kegiatan pengumpulan sampah adalah membersihkan jalan raya yang sekaligus merupakan proses yang dilakukan untuk menjaga kebersihan jalan dari segala jenis sampah. Berikut hasil wawancara dengan Kepala Dinas Tata Ruang dan Cipta Karya Kabupaten Bulukumba terkait dengan pengumpulan sampah yang dilakukan:

"Berbicara mengenai teknisnya, itu dilakukan oleh petugas kebersihan yang mengumpulkan sampah di jalan, dimana para petugas menyapu sampah yang ada di jalan raya kemudian mengumpulkannya di bak-bak sampah yang ada di pinggir jalan." (wawancara PA.).

Analisis dari hasil wawancara dengan informan terkait dengan bentuk teknis pengumpulan sampah yang dilakukan adalah untuk masalah teknis 
pembersihan atau pengumpulan sampah itu dilakukan oleh petugas kebersihan, dimana para petugas penyapu mengumpulkan sampah tersebut kedalam wadah yang telah di siapkan.

Senada dengan itu, Kepala Bidang Sarana dan Prasarana Dinas Tata Ruang dan Cipta Karya Kabupaten Bulukumba mengatakan bahwa:

"Kalau bentuk teknis dari pengumpulan sampah itu sendiri adalah para petugas penyapu jalanlah yang melakukan pengumpulan tersebut. Para petugas tersebut mengumpulkan sampah yang berserakan di pinggir jalan kemudian menyatukannya dalam satu wadah yang nantinya akan diangkut oleh petugas yang lainnya." (Wawancara dengan MS)

Analisis dari hasil wawancara dengan informan adalah bentuk teknis dari pengumpulan sampah ialah para petugas penyapu jalan mengumpulan sampah di pinggir jalan dalam satu wadah yang kemudian nantinya akan diangkut oleh petugas lainnya. Lanjut dari itu Kepala Seksi Kebersihan, Pertanaman dan Pemakaman Dinas Tata Ruang dan Cipta Karya Kabupaten Bulukumba juga mengatakan bahwa:

"Dalam melakukan pengumpulan sampah kami telah melakukan apa yang kemudian menjadi tugas kami. Hal ini dilakukan oleh para petugas menyapu jalan mulai hari senin-sabtu kecuali petugas yang bertugas di dalam pasar sentral/terminal tetap bekerja pada hari minggu. Tidak seperti di daerah lain yang mungkin petugas penyapunya bergantian mulai dari pagi, siang dan sore, hal seperti ini terjadi karena persoalan anggaran dan bahkan tidak semua jalan disapu oleh petugas, oleh sebab itu kebersihan jalan tidak dapat tercipta secara maksimal. Tetapi meskipun seperti itu sejauh ini pemerintah sangat bersyukur dengan keterlibatan masyarakat secara langsung yang sadar akan lingkungannya." (wawancara AA)

Analisis dari hasil wawancara dengan informan terkait dengan bentuk teknis pengumpulan sampah yang dilakukan adalah Seksi Kebersihan, Pertanaman dan Pemakaman mengumpulkan sampah kedalam bak-bak yang ada di pinggir jalan dan telah melakukan pembagian tugas bagi para petugas penyapu jalan untuk melakukan pengumpulan sampah serta menetapkan jadwal dari para petugas tersebut. Dialain sisi keterlibatan masyarakat dengan kesadarannya akan lingkungan sangat membantu tugas dari pemerintah.

b. Pengangkuatan Sampah

Pengangkutan sampah merupakan proses pemindahan sampah dari suatu tempat ke tempat lain. Berikut hasil wawancara dengan Kepala Dinas Tata Ruang dan Cipta Karya Kabupaten Bulukumba terkait dengan pengangkuatan sampah yang menyatakan bahwa:

"Untuk tahap pengangkutan itu terbagi dua, yakni: pengangkutan dari sumber ke TPS, selanjutnya dari TPS ke TPA (dilakukan oleh petugas pengangkut, pengangkuatan ini dilakukan dengan cara sampah yang sebelumnya terkumpul di TPS kemudian diangkat menggunakan amb roll/mobil sampah dan ada juga truk dan pic up yang langsung membawa sampah tersebut dati TPS ke TPA)."

(wawancara PA).

Analisis dari hasil wawancara dengan informan terkait dengan upaya pengangkuatan sampah yang dilakukan adalah ada dua tahap pengangkuatan yang dilakukan yakni pengangkuatan dari sumber ke TPS dengan menggunakan 
motor sampah dan dari TPS ke TPA dengan menggunakan amb roll, truk dan pic up. Senada dengan itu, Kepala Bidang Sarana dan Prasarana Dinas Tata Ruang dan Cipta Karya Kabupaten Bulukumba mengatakan bahwa:

"Bentuk teknis dari pengangkutan sampah yang dilakukan adalah sampah-sampah yang sebelumnya telah dikumpulkan oleh petugas penyapu jalan, begitupun dengan yang telah terkumpul dalam bakbak sampah yang ada di pinggir jalan kemudian diangkut ke tempat pembuangan sementara (TPS) menggunakan motor sampah dan selanjutnya diangkut lagi ke tempat pembuangan akhir (TPA) dengan menggunakan amb roll, truk dan pic up oleh masingmasing petugasnya." (Wawancara MS)

Analisis dari hasil wawancara dengan informan adalah para petugas pengangkut mengambil/mengangkut sampah yang telah terkumpul sebelumnya dalam wadah menuju TPS yang selanjutnya diangkut lagi menuju TPA oleh masing-masing petugasnya. Lanjut dari itu Kepala Seksi Kebersihan, Pertanaman dan Pemakaman Dinas Tata Ruang dan Cipta Karya Kabupaten Bulukumba juga mengatakan bahwa:

"Dalam proses pengangkutan sampah dari sumber (kantor, rumah tangga, hotel, bak-bak penampungan) ke TPS, kami menggunakan motor sampah. Motor sampah kami pilih untuk menjadi alat pengangkut dari sumber ke TPS karena dianggap lebih efektif dan efisien untuk menjangkau lorong-lorong sempit yang tidak bisa dijangkau oleh kendaraan pengangkut yang lebih besar. Sedangkan untuk pengangkutan dari TPS ke TPA, Dalam proses ini kami menggunakan mobil pengangkut yang volume muatannya lebih banyak dari motor sampah, yakni: amb roll, truk dan pic-up." (wawancara AA).

Analisis dari hasil wawancara dengan informan terkait dengan pengangkuatan sampah yang dilakukan adalah dalam melakukan pengangkuatan sampah dari sumber ke TPS itu menggunakan motor sampah, dipilihnya motor sampah sebagai alat pengangkut ini karena dianggap lebih efektif dan efisien. Sedangkan untuk mengangkut sampah dari TPS ke TPA digunakan alat pengangkut yang volume muatannya lebih besar dibandingkan dengan yang mengangkut ke TPS. Disamping itu para petugas tetap berusaha untuk menjaga kondisi kota dalam keadaan bersih meskipun fasilitas yang digunakan masih kurang.

\section{c. Pemusnahan Sampah}

Pemusnahan merupakan proses menghancuran sampah yang dilakukan di TPA. Dalam proses ini tiap daerah menggunakan metode berbeda-beda di tiap daerah, tergangtung dari kebijakan yang di ambil pemerintahnya. Berikut hasil wawancara dengan Kepala Dinas Tata Ruang dan Cipta Karya Kabupaten Bulukumba terkait dengan upaya pemusnahan sampah menyatakan bahwa:

"Pemusnahan sampah kami lakukan dengan metode Sanitary Lanfiil dimana pemusnahan ini kami anggapa paling baik karena tidak membiarkan sampah berada di ruang terbuka." (wawancara PA).

Analisis dari hasil wawancara dengan informan terkait dengan metode pemusnahan sampah yang dilakukan adalah dalam melakukan pemusnahan sampah, Dinas Tata Ruang dan Cipata Karya menggunakan metode sanitary landfiil dengan tidak membiarkan sampah-sampah berada di ruang terbuka. 
Senada dengan itu, Kepala Bidang Sarana dan Prasarana Dinas Tata Ruang dan Cipta Karya Kabupaten Bulukumba mengatakan bahwa:

"Pada tahap pemusnahan ini kami menggunakan metode penimbunan atau juga biasa disebut dengan Sanitary Lanfiil. Metode tersebut kami gunakan karena menurut kami metode tersebutlah yang paling tepat untuk kami terapkan. Penetapan metode tersebut didukung dengan tersedianya lahan TPA yang luas" (Wawancara MS)

Analisis dari hasil wawancara dengan informan adalah metode pemusnahan sampah yang digunakan yaitu metode sanitary lanfiil, dimana metode inilah yang dianggap paling tepat untuk digunakan karena dapat meminimalisir pencemaran lingkungan yang disebabkan oleh sampah itu sendiri. Lanjut dari itu Kepala Seksi Kebersihan, Pertanaman dan Pemakaman Dinas Tata Ruang dan Cipta Karya Kabupaten Bulukumba juga mengatakan bahwa:

"Untuk tahap pemusnahan sampah, kami melakukannya dengan cara menimbun sampah tersebut dengan tanah selapis demi selapis." (wawancara AA).

Analisis dari hasil wawancara dengan informan terkait dengan metode pemusnahan sampah yang dilakukan adalah dalam melakukan pemusnahan digunakan metode penimbunan sampah dengan tanah selapis demi selapis hal ini bertujuan agar bau dari sampah tersebut tidak mencemari udara.

\section{d. Pengawasan}

Pengawasan merupakan sebuah kegiatan memantau pekerjaan yang dilakukan oleh orang lain atau bawahan. Pengawasan pada dasarnya diarahkan sepenuhnya untuk menghindari adanya kemungkinan penyelewengan atau penyimpangan atas tujuan yang akan dicapai. Melalui pengawasan diharapkan dapat membantu melaksanakan kebijakan yang telah ditetapkan untuk mencapai tujuan yang telah direncanakan secara efektif dan efisien. Bahkan, melalui pengawasan tercipta suatu aktivitas yang berkaitan erat dengan penentuan atau evaluasi mengenai sejauh mana pelaksanaan kerja sudah dilaksanakan. Pengawasan juga dapat mendeteksi sejauh mana kebijakan pimpinan dijalankan dan sampai sejauh mana penyimpangan yang terjadi dalam pelaksanaan kerja tersebut. Berikut hasil wawancara dengan Kepala Dinas Tata Ruang dan Cipta Karya Kabupaten Bulukumba terkait dengan upaya pemusnahan sampah menyatakan bahwa:

"Proses pengawasan yang kami lakukan adalah pengawasan langsung, yaitu dengan cara turun langsung kelapangan meninjau hasil kerja dari para petugas kebersihan." (wawancara $P A)$.

Analisis dari hasil wawancara dengan informan adalah dalam melakukan pengawasan, Dinas Tata Ruang dan Cipta Karya melakukan pengawasan langsung yaitu dengan cara turun langsung ke lapangan untuk mengawasi para petugas kebersihan. Senada dengan itu, Kepala Bidang Sarana dan Prasarana Dinas Tata Ruang dan Cipta Karya Kabupaten Bulukumba mengatakan bahwa:

"Dalam melakukan pengawasan terhadap pengelolaan sampah, mulai dari pengumpulan, pengangkutan dan pemusnahan sampah, kami melakukannya dengan cara petugas pengawas pengelolaan sampah turun langsung kelapangan untuk mengawasi hasil kerja dari para petugas yang mengumpulkan, mengangkut dan memusnahkan sampah tersebut." (Wawancara MS) 
Analisis dari hasil wawancara dengan informan adalah proses pengawasan yang dilakukan yaitu dengan cara petugas pengawas Dinas Tata Ruang dan Cipta Karya Kabupaten Bulukumba turun langsung ke lapangan untuk mengawasi jalannya proses pengelolaan sampah tersebut. Lanjut dari itu Kepala Seksi Kebersihan, Pertanaman dan Pemakaman Dinas Tata Ruang dan Cipta Karya Kabupaten Bulukumba juga mengatakan bahwa:

"Untuk proses pengawasan yang kami lakukan yaitu dengan cara turun langsung ke lapangan untuk mengawasi para petugas dalam menjalankan pekerjaannya. Dimana pada tahap pengumpulan sampah yang terbagi ke dalam 10 zona itu, kami menempatkan masing-masing 1 orang pengawas pada tiap zona, untuk tahap pengangkuatan dari sumber ke TPS oleh motor sampah kami menempatkan 1 orang pengawas dan untuk pemusnahan di TPA kami menempatkan 2 orang pengawas yang juga mengawasi proses pemusnahan sampah tersebut." (wawancara AA).

Analisis dari hasil wawancara dengan informan adalah dalam melakukan pengawasan terhadap pengelolaan sampah, itu dilakukan dengan cara turun langsung ke lapangan untuk mengawasi jalannya proses pengelolaan tersebut mulai dari tahap pengumpulan, pengangkuatan dan pemusnahan sampah. Lebih dari itu sebagai pengawas, dalam proses pengelolaan sampah di Kabupaten Bulukumba pengawasan dilakukan dengan cara turun langsung ke lapangan serta membentuk tim pengawas pada tiap tahap pengelolaan sampah mulai dari tahap pengumpulan, pengangkuatan dan pemusnahan untuk mengawasi jalannya proses pengelolaan sampah tersebut.

\section{Faktor-Faktor Yang Mempengaruhi Pengelolaan Sampah Di Kabupaten Bulukumba}

Terkait faktor-faktor yang mempengaruhi kesuksesan kebijakan pemerintah daerah dalam pengelolaan sampah tentunya hadir faktor pendukung dan faktor penghambat. Adapun yang menjadi faktor pendukung yakni:

\section{1) Adanya Partisipasi Masyarakat}

Partisipasi masyarakat merupakan keikutsertaan masyrakat dalam suatu kegiatan. Dengan adanya perubahan cara pandang masyarakat ke arah yang positif dapat menjadi sebuah faktor pendukung dalam proses perubahan. Berikut hasil wawancara dengan Kepala Dinas Tata Ruang dan Cipta Karya Kabupaten Bulukumba terkait dengan kondisi sosial masyarakat sebagai faktor pendukung pengelolaan sampah menyatakan bahwa:

"Partisipasi masyarakat dikategorikan sebagai faktor pendukung dalam pengelolaan sampah, karena masyarakat saat ini sudah mulai sadar terhadap kondisi lingkungan mereka. Dengan adanya kesadaran dari masyarakat dapat membantu terwujudnya kondisi lingkungan yang nyaman serta juga dapat membantu dalam pencapaian tujuan pemerintah yang telah ditetapkan sebelumnya yaitu kondisi lingkungan yang bersih." (wawancara PA).

Analisis hasil wawancara dengan informan adalah dengan adanya kesadaran masyarakat terhadap kondisi lingkungan sekitar mereka dapat membantu mewujudkan kondisi lingkungan yang nyaman serta dapat juga membantu tercapainya tujuan pemerintah akan lingkungan yang bersih. Senada dengan itu, Kepala Bidang Sarana dan Prasarana Dinas Tata Ruang dan Cipta Karya 
Kabupaten Bulukumba mengatakan bahwa:

"Karena saat ini yang saya lihat sendiri itu, cara pandangan masyarakat terhadap kondisi lingkungan sekitarnya sudah berbeda dari sebelumnya. Dimana yang sebelumnya acuh terhadap kondisi lingkungan sekitarnya, sekarang dengan adanya kesadaran mereka justru ikut menjaga keindahan lingkungan yang salah satu cara mereka yaitu tidak membuang sampah pada sembarang tempat." (Wawancara MS)

Analisis dari hasil wawancara dengan informan adalah dengan adanya perubahan cara pandang masyarakat terhadap kondisi lingkungan sekitar dapat membawa dampak positif yaitu masyarakat kemudian menjadi turut serta dalam menjaga keindahan lingkungan. Lanjut dari itu Kepala Seksi Kebersihan, Pertanaman dan Pemakaman Dinas Tata Ruang dan Cipta Karya Kabupaten Bulukumba juga mengatakan bahwa:

"Karena Masyarakat saat ini yang saya lihat di lapangan sudah mulai sadar akan pentingnya kebersihan di lingkungan sekitar mereka, mereka tidak lagi menganggap bahwa kebersihan itu adalah tanggung jawab dari pemerintah, melainkan mereka sudah mulai menganggap bahwa kebersihan lingkungan itu adalah tanggung jawab kita bersama dan harus kita wujudkan bersama. Sebagai salah satu contoh kesadaran masyarakat adalah mereka selalu membantu para petugas pengangkut yang menggunakan motor sampah di dalam melaksanakan tugasnya." (wawancara AA).

Analisis dari hasil wawancara dengan informan adalah cara pandang masyarakat yang dilihat oleh Kepala Seksi Kebersihan, Pertanaman dan Pemakaman Dinas Tata Ruang dan Cipta Karya Kabupaten Bulukumba yaitu masyarakat sudah mulai sadar bahwa kebersihan lingkungan sekitar merupakan tanggung jawab bersama serta harus diwujudkan bersama-sama pula. Lebih dari itu, para tokoh masyarakat mengatakan bahwa:

"Kalau yang saya lihat di lapangan itu, masyarakat saat ini sebagian besar sudah mulai sadar akan kondisi lingkungannya. Mengapa saya katakan demikian, karena sering kali saya lihat masyarakat tidak lagi membuang sampah sembarang tempat ditambah juga mereka biasa membantu para petugas motor sampah untuk mengangkut sampah yang ada di bak-bak sampah ke dalam motor sampah tersebut." (Wawancara YA.).

Analisis dari hasil wawancara dengan informan adalah saat ini sebagian besar masyarakat sudah mulai sadar akan kondisi lingkungan mereka. Sebagai contoh mereka tidak lagi membuang sampah sembarang tempat serta mereka biasa membantu para petugas motor sampah dalam melaksanakan tugasnya.

"Bentuk partisipasi masyarakat dalam pengelolaan sampah yang sering saya lihat adalah sebagian besar masyarakat sering saya lihat membantu petugas motor sampah untuk mengangkut sampah-sampah yang ada di dalam bak-bak penampungan yang akan di bawah ke TPS." (Wawancara MA)

Analisis dari hasil wawancara dengan informan adalah sebagian besar masyarakat sering membantu petugas motor sampah dalam melakukan tugasnya, yakni melakukan pengangkuatan sampah yang ada di bak-bak sampah. 
"Seperti yang sering saya lihat di lapangan, sebagian besar masyarakat sudah mulai turut serta dalam menjaga lingkungan sekitar. Adapun bentuk kegiatan yang mereka lakukan adalah tidak lagi membuang sampah sembarang tempat serta sering membantu petugas pengangkut yang menggunakan motor sampah dalam proses pengangkuatan sampah yang ada di bak-bak sampah." (Wawancara JU).

Analisis dari hasil wawancara dengan informan adalah sebagian besar masyarakat sudah mulai sadar serta menjaga lingkungan sekitar mereka, adapun bentuk kepedulian yang mereka lakukan adalah tidak lagi membuang sampah sembarang tempat dan sering juga membantu petugas motor sampah dalam melakukan tugasnya.

"Bentuk partisipasi masyarakat yang sering saya lihat di lapangan adalah masyarakat tidak lagi membuang sampah di sembarang tempat. Mereka membuang sampah mereka di tempat yang telah disiapkan, kalau bukan pada bak-bak sampah maka mereka akan langsung membawanya sendiri ke TPS. Selain itu saya juga sering melihat masyarakat membantu petugas motor sampah untuk mengangkut sampah yang ada di bak-bak sampah." (Wawancara MA).

Analisis dari hasil wawancara dengan informan adalah sebagai bentuk partisipasi masyarakat tidak lagi membuang sampah sembarang tempat, melainkan mereka membuang sampah pada tempat yang telah disediakan, ditambah juga masyarakat selalu turut berpartisipasi dalam pengangkuatan sampah yang aka di dawah ke TPS.

\section{2) Lahan TPA Yang Luas}

Tempat Pembuangan Akhir (TPA) merupakan tempat dimana sampah mencapai tahap terakhir dalam pengelolaannya sejak mulai timbul di sumber, pengumpulan, pemindahan/pengangkutan, pengolahan dan pembuangan. TPA merupakan tempat dimana sampah diisolasi secara aman agar tidak menimbulkan gangguan terhadap lingkungan sekitarnya. Karenanya diperlukan penyediaan fasilitas dan perlakuan yang benar agar keamanan tersebut dapat dicapai dengan baik. Berikut hasil wawancara dengan Kepala Dinas Tata Ruang dan Cipta Karya Kabupaten Bulukumba terkait dengan lahan TPA sebagai faktor pendukung pengelolaan sampah menyatakan bahwa:

"Dengan adanya lahan TPA yang luas, maka kami secara leluasa dapat melakukan isolasi terhadap sampah pada proses pengelolaan akhirnya serta kami juga dapat melakukan proses pengelolaan yang terbaik terhadap sampahsampah tersebut." (wawancara $P A)$.

Analisis dari hasil wawancara dengan informan adalah dengan tersedianya lahan TPA yang luas dapat memudahkan bagi pengelolah sampah untuk melakukan proses pengelolaan akhir sampah di TPA. Senada dengan itu, Kepala Bidang Sarana dan Prasarana Dinas Tata Ruang dan Cipta Karya Kabupaten Bulukumba mengatakan bahwa:

"Dengan tersedianya lahan TPA yang begitu luas, yang saat ini luasnya ada sekitar \pm 1 hektar dapat memudahkan kami untuk melakukan proses pemusnahan terhadap sampah-sampah tersebut." (Wawancara MS)

Analisis dari hasil wawancara dengan informan adalah dengan adanya lahan TPA yang luas dapat memudahkan 
proses pemusnahan sampah yang ada di TPA. Lanjut dari itu Kepala Seksi Kebersihan, Pertanaman dan Pemakaman Dinas Tata Ruang dan Cipta Karya Kabupaten Bulukumba juga mengatakan bahwa:

"Dengan luasnya lahan TPA yang tersedia saat ini sangat memudahkan bagi kami dalam melakukan pemusnahan sampah di TPA. Luas lahan TPA yang kami miliki saat ini adalah \pm 1 hektar, tapi saat ini lahan tersebut sudah hampir tidak dapat kami gunakan lagi, olehnya itu saat ini kami sedang melakukan pembukaan jalan menuju lahan TPA kami yang baru dengan luas \pm 3 hektar dan insya Allah dapat kami gunakan dalam beberapa bulan kedepan." (wawancara AA).

Analisis dari hasil wawancara dengan informan adalah luas lahan TPA sangat berpengaruh terhadap proses pengelolaan sampah. Dengan tersedianya lahan TPA yang luas dapat memudahkan proses pemusnahan sampah bagi pengelolah kebersihan. Adanya perubahan pemahaman masyarakat kearah yang positif terhadap kebersihan lingkungan sekitar mampu menjadi faktor penunjang dalam mewujudkan lingkungan yang bersih, serta dengan tersedianya lahan TPA yang luas dapat mempermudah dalam proses pemusnahan sampah di TPA.

Selain faktor pendukung yang melancarkan proses pengelolaan sampah di Kabupaten Bulukumba tentunya terdapat faktor penghambat yang menjadi acuan serta tantangan bagi pemerintah daerah dan masyarakat. Adapun yang menjadi faktor penghambat dalam pengelolaan sampah di daerah Bulukumba yakni:

\section{1) Kurangnya Sumber Daya Manusia} (SDM)
Sumber daya manusia merupakan kemampuan terpadu dari daya pikir dan daya fisik yang dimiliki individu. Berikut hasil wawancara dengan Kepala Dinas Tata Ruang dan Cipta Karya Kabupaten Bulukumba terkait dengan SDM sebagai faktor penghambat pengelolaan sampah menyatakan bahwa:

"Sumber Daya Manusia
dikategorikan sebagai faktor
penghambat dalam pengelolaan
sampah karena tidak adanya
tenaga-tenaga ahli yang bekerja
dalam proses pengelolaan sampah,
ditambah dengan masih
kurangnya tenaga pengumpul dan
pengangkut sampah."
(wawancara PA)

Analisis dari hasil wawancara dengan informan adalah sumber daya manusia dikatakan sebagai faktor penghambat karena masih kurangnya tenaga kebersihan yang bekerja dalam proses pengelolaan sampah. Senada dengan itu, Kepala Bidang Sarana dan Prasarana Dinas Tata Ruang dan Cipta Karya Kabupaten Bulukumba mengatakan bahwa:

"Saat ini sumber daya manusia yang dimiliki oleh Dinas Tata Ruang dan Cipta Karya Kabupaten Bulukumba, khususnya yang bertugas di bagian kebersihan masih sangat minim jika dibandingkan dengan luas lokasi yang harus dibersihkan." (Wawancara MS)

Analisis dari hasil wawancara dengan informan adalah sumber daya manusia dianggap menjadi salah satu faktor penghambat dalam pengelolaan sampah karena masih minimnya petugas yang bekerja di bagian kebersihan jika dibandingkan dengan luas lokasi yang harus dibersihkan.

Lanjut dari itu Kepala Seksi Kebersihan, Pertanaman dan Pemakaman Dinas Tata Ruang dan Cipta Karya 
Kabupaten Bulukumba juga mengatakan bahwa:

"Sumber daya manusia yang tersedia saat ini khususnya dibagian kebersihan itu masih sangat minim, dimana kami saat ini hanya memiliki 143 tenaga kebersihan dengan spesifikasi: 98 orang petugas penyapu jalan, 10 orang pengawas penyapu jalan, 15 orang petugas motor sampah, 1 orang pengawas motor sampah, 16 orang petugas mobil yang mengangkut ke TPA, 2 orang pengawas TPA dan 1 orang operator alat berat. Jika dibandingkan dengan luas lokasi yang harus kita jaga kebersihannya yakni $14,44 \mathrm{~km}^{2}$ maka jumlah petugas kami sangat jauh dari kata cukup untuk menjaga kondisi kebersihan tersebut, oleh karena itu kami menetapkan hanya jalan-jalan besar dalam kota yang disapu oleh petugas penyapu jalan." (wawancara $A A$ ).

Hasil wawancara menunjukkan adanya ketimpangan antara beban pekerjaan dengan pekerja. Ditambah dengan luas lokasi yang harusnya dijaga kebersihannya, jumlah petugas kebersihan Dinas Tata Ruang dan Cipta Karya Kabupaten Bulukumba masih sangat sedikit untuk menjaga kondisi kebersihan lingkungan, olehnya itu ditetapkan oleh Dinas Tata Ruang dan Cipta Karya Kabupaten Bulukumba hanya jalan-jalan besar dalam kota yang disapu oleh petugas penyapu jalan.

2) Masih Minimnya Sarana dan Prasarana Yang Tersedia

Sarana merupakan fasilitas utama yang digunakan untuk mencapai tujuan sedangkan prasarana merupakan fasilitas pendukung yang digunakan untuk mencapai tujuan. Berikut hasil wawancara dengan Kepala Dinas Tata Ruang dan Cipta Karya Kabupaten Bulukumba terkait dengan Sarana dan Prasarana sebagai faktor penghambat pengelolaan sampah menyatakan bahwa:

"Sarana dan prasarana juga dikategorikan sebagai faktor penghambat khususnya dalam pengelolaan sampah karena sampai pada saat ini fasilitas yang kami miliki itu belum cukup memadai untuk digunakan dalam proses pengelolaan sampah." (wawancara PA).

Analisis dari hasil wawancara dengan informan adalah sarana dan prasarana dikategorikan sebagai faktor penghambat dalam proses pengelolaan sampah karena fasilitas-fasilitas yang tersedia saat ini belum cukup memadai untuk digunakan dalam proses pengelolaan sampah. Senada dengan itu, Kepala Bidang Sarana dan Prasarana Dinas Tata Ruang dan Cipta Karya Kabupaten Bulukumba mengatakan bahwa:

"Jadi khusus untuk bagian kebersihan, sarana dan prasarana dikatakan sebagai salah satu faktor penghambat dalam proses pengelolaan sampah karena baik sarana maupun prasarana yang kami miliki saat ini belum cukup memadai untuk kami gunakan dalam proses pengelolaan sampah. Adapun sarana yang kami miliki saat ini terdiri dari: Bak penampungan sampah ada \pm 300 pasang termasuk yang dipakai oleh petugas penyapu jalan, Motor sampah ada 15, Amrol 4, truk 2 dan pic-up 2, Bak sampah amrol ada 16, Eskafator 1 buah dan untuk prasarana sebagai fasilitas penunjang pengelolaan sampah juga belum cukup memadai." (Wawancara MS). 
Analisis dari hasil wawancara dengan informan adalah baik sarana dan prasarana Dinas Tata Ruang dan Cipta Karya Kabupaten Bulukumba yang tersedia saat ini itu belum cukup memadai untuk digunakan dalam proses pengelolaan sampah, oleh sebab itu sarana dan prasarana dikategorikan sebagai salah satu faktor penghambat dalam pengelolaan sampah. Lanjut dari itu Kepala Seksi Kebersihan, Pertanaman dan Pemakaman Dinas Tata Ruang dan Cipta Karya Kabupaten Bulukumba juga mengatakan bahwa:

"Sarana dan prasarana kami anggap sebagai salah satu faktor penghambat dalam proses pengelolaan sampah karena sampai pada saat ini fasilitasfasilitas tersebut jumlahnya masih sangat minim dan bahkan ada dari beberapa fasilitas yang tersedia saat ini rusak, seperti bak sampah amrol ada dua buah yang sudah harus kami perbaiki, serta belum adanya komputer yang seharusnya kami gunakan untuk menginput data-data yang ada." (wawancara $A A$ ).

Analisis dari hasil wawancara dengan informan adalah sarana dan prasarana dianggap sebagai salah satu faktor penghambat dalam proses pengelolaan sampah karena fasilitasfasilitas yang tersedia saat ini masih belum memadai untuk digunakan dalma proses pengelolaan sampah. Keberadaan sumber daya manusia tidak selamanya menjadi faktor pendukung dalam setiap kegiatan, terkadang sumber daya manusia sendiri bisa menjadi faktor penghambat dalam mencapai suatu tujuan. Begitupun dengan sarana dan prasarana sebagai fasilitas yang akan digunakan bisa menjadi faktor penghambat.

\section{E. PENUTUP}

Berdasarkan hasil penelitian di Kabupaten Bulukumba, maka dapat disimpulkan bahwa:

1. Didalam melaksanakan peran sebagai pengelolah sampah di Kabupaten Bulukumba, Dinas Tata Ruang dan Cipta Karya Kabupaten Bulukumba bertindak sebagai implementor atau sebagai pelaksana kebijakan sekaligus sebagai pengawas terhadap jalannya kegiatan pengelolaan sampah. Didalam mengaplikasikan kedua peran tersebut, sampai saat ini Dinas Tata Ruang dan Cipta Karya Kabupaten Bulukumba belum bisa menunjukkan hasil yang diharapkan oleh banyak orang;

2. Dalam melaksanakan peran sebagai pengelolah sampah terdapat dua faktor yang mempengaruhi hasil dari kinerja Dinas Tata Ruang dan Cipta Karya Kabupaten Bulukumba, yaitu adanya faktor pendukung (adanya partisipasi masyarakat serta tersedianya lahan TPA yang luas) dan faktor penghambat (SDM yang masih kurang serta masih minimnya sarana dan prasarana yang tersedia). Diantara kedua faktor tersebut, faktor penghambat lebih mendominasi hasil dari kinerja Dinas Tata Ruang dan Cipta Karya Kabupaten Bulukumba sehingga membuat tujuan yang ingin dicapai bersama belum bapat terwujud.

Dengan memperhatikan kesimpulan diatas dan menganalisis pembahasan pada bab-bab sebelumnya maka penulis merasa perlu memberikan masukan sebagai berikut:

1. Untuk lebih mengoptimalkan peran pengelolaan sampah yang dilaksanakan oleh Dinas Tata Ruang dan Cipta Karya, maka sebaiknya peningkatan kesadaran masyarakat dapat lebih diupayakan serta pelibatan masyarakat dalam hal 
pengawasan juga dapat diwujudkan;

2. Terkait masalah faktor-faktor yang mempengaruhi pengelolaan sampah, agar kiranya dapat diupayakan sosialisasi rutin mengenai pengelolaan sampah kepada masyarakat. Diharapkan dengan adanya sosialisasi tersebut dapat meningkatkan kesadaran masyarakat terhadap lingkungannya, sehingga keberadaan faktor pendorong dapat lebih mendominasi yang kemudian akan menghasilkan hasil yang maksimal.

\section{DAFTAR PUSTAKA}

Afandi, Fian, 2010. Konsep Pengelolaan Sampah Di Masyarakat http://fianafandi.wordpress.com/20 10/05/24/konsep-pengelolaansampah-di-masyarakat/ Pada 28 April 2015

Bahagia, 2009. Peran Pemerintah Daerah dan Partisipasi Masyarakat Dalam
Rehabilitasi Hutan Mangrove, Sumatra: Universitas Sumatra Utara

Khoiriyah, Siti, 2010. Faktor Yang Mempengaruhi Partisipasi

Masyarakat Dalam Pengolaan Sampah $3 R, \quad$ Semarang: Universitas Diponegoro

Liata, Nofal, 2012. Pelayanan Masyarakat Dalam Lembaga Pemerintah. http://nofalliata.wordpress.com/20 12/08/26/pelayanan-masyarakatdalam lembaga pemerintah/ Pada 13 Juli 2015

\section{Perundang-undangan :}

Undang-Undang Nomor 18 Tahun 2008 Tentang Pengelolaan Sampah.

Undang-Undang Nomor 32 Tahun 2004 Tentang Pemerintah Daerah. 